\title{
The method of improvement of quality of life \\ of older people as users and maintainers \\ of technical means in Smart City
}

doi:10.2478/mape-2019-0029

Date of submission to the Editor: 04/2018

Date of acceptance by the Editor: 07/2018

MAPE 2019, volume 2, issue 1, pp. 296-304

Andrzej Wieczorek

ORCID ID: 0000-0002-6911-9726

Silesian University of Technology, Poland

Danuta Zarebinska

Atria logic INC, USA

Wojciech Kaniak

Rexroth Bosch Group Canada, Canada

\section{INTRODUCTION}

The quality of life as a degree of satisfaction of material and non-material needs is a concept used in social policy, psychology, medicine, economics and sociology. Unfortunately, it is not used in engineering sciences, and there is a need to use it, because people satisfy more or less specific needs by using or maintaining technical means. This subject is very widely reflected in practice. In many cases it concerns people who have problems with adapting to dynamic changes related to the development of technology in their workplaces. This condition causes reluctance to introduce changes and limits the development possibilities of these people. This is clearly visible in the mining industry, where conservative approaches are quite conservative, but they are necessary due to the enormous competition on the energy commodity market and the dangerous conditions under which mining is carried out (Brodny \& Tutak, 2018, Brodny \& Tutak, 2018a, Tutak \& Brodny, 2019). In this case, the problem concerns people of working age who have problems with adapting to changes in the workplace (Palka et al., 2017, Palka, 2017).

In the case of older people this problem is even more complex. It concerns everyday life, which in many cases can significantly hinder the lives of these people in the world of more and more advanced technical means.

An example of such technical means are solutions used in transport, which are exploited by people of all ages, including the older people. Because of problems with mismatch of such people into the means of transport, many of them do not leave the house. Problems of seniors with technical solutions are also present at the stage of travel planning by such persons, in walking, traveling by public transport and driving. These problems will become more and more burdensome as the number of older people grows and will grow in societies.

The answer to the problems of the older people, appearing in transport systems and the resulting need to improve the quality of life can be solutions in the area of a smart

\footnotetext{
”andrzej.wieczorek@polsl.pl
} 
city. Implementation of technical measures in the smart city area will be effective if it is preceded by appropriately conducted social participation, aimed at identifying and analyzing the existing needs of the local community.

In opposition to the need to guarantee human participation in the functioning of public transport, the philosophy of technology assessment comes out. Therefore, the article presents a study of literature on the problem of improving the quality of life of older people as users and maintainers of technical means in a smart city. In the first step, attention was paid to the needs of older people as users and maintainers of technical means of transport. In the next step, attention was paid to the engineering response to these needs. The answer includes, among others, the concept of an indicator that will allow to assess the quality of life of older people in the area being considered.

\section{TRANSPORT IN SMART CITY - A STUDY OF LITERATURE}

The implementation of means and ways to improve the quality of life of older people in the transport of a smart city should be preceded by studies aimed at answering the

following questions (Kaźmierczak, 2019):

- what do we intend to achieve as a result of the implementation of the smart city concept?

- what is the implementation of the smart city concept for?

- who participates in this task and how?

- how are we going to get the expected result of smart city implementation?

The answer to the first question is conditioned by the definition of the quality of life, which is understood as the degree of satisfaction of material and non-material needs (PWN Dictionary). These needs may be met as a result of the participation of an older person in the exploitation of transport means and systems belonging to the following modes of transport (classification by type of environment):

- terrestrial transport: overground, (e.g. overhead cableway), underground (e.g. subway), rail (railroad), trackless (road, bus transport);

- water transport;

- air transport;

- wired transport (pipeline, transmission or conveyor).

Due to the interest of the authors of the article, the subject of further consideration will be public transport systems, using bus transport (public transport buses) and pipeline systems transporting water.

Implementation of solutions in the discussed transport systems should result from the goal (answer to question 2), which is the necessity to meet the needs of the elderly as users or maintainers of technical means or managing their exploitation systems. Movement of older people allows them to participate in associations and organizations, entertainment events, social interaction and independence. Means of transport guarantee the necessary communication connection to such persons with other people, they give a sense of independence in society. Holes in the sidewalks, high curbs, closed lifts, high levels, overcrowded buses, driving vehicles entering the belts at excessive speed, broken traffic lights, uncovered stops, slippery surfaces cause that the elderly are reluctant to leave the house (Wnuk \& Grabarczyk, 2006). According to (Wnuk \& Grabarczyk, 2006) for (DETR Report), the most problems for the elderly are caused by: planning the trip: lack of information, insufficient 
accessibility of transport services, transport network that does not meet their needs, long distance to the destination, lack of seating and lighting at the bus stop, distance vehicle from the platform or from the bus stop, lack of public acceptance and voluntary transport alternatives, parked vehicles; walking: large and fast traffic, lack of amenities at intersections and difficulties in overcoming them, poor condition of pavements and obstacles on the pavements, no sidewalks, difficulties in using local services, such as post offices, pharmacies and banks, increased risk of accident; traveling by public transport: problems with getting on and off, high levels, high costs of travel, low frequency of trips, unreliable routes, uncomfortable driving, driving: costs of buying, obtaining permits, maintaining and operating the vehicle, bad visibility at intersections, invisible and difficult to read road signs, discrimination by insurance companies. From using the means of transport, which are buses, in addition to architectural barriers, potential users also restrains poor access to information. Older people are more susceptible to injuries, they recover more quickly after their occurrence, they more strongly experience them from the psychic side, they react more slowly and have worse perception. Traveling in the crowd, with no possibility of leaning or holding the handrail at the appropriate height, sudden braking causes them to lack selfconfidence and a reduced sense of value as a participant of the movement in relation to younger people.

The quality of life of water network operators can be assessed on the basis of situations in which they experience stress (e.g. nervousness, frustration) resulting from the use of these technical measures. Stress can be varied depending on, for example, gender or age. It may be the result of too long time of water supply network shutdown (resulting from a long waiting time for its repair) or too frequent occurrence of repair. The frustration can be caused by dirty water appearing in the tap, too long waiting for a water tank with useable water, the fact that the workers carrying out the network repair are on the house, while the sense of powerlessness in seniors may trigger the necessity of moving two buckets with water from the water cart to the house (Kaźmierczak et al., 2017).

A separate group of older people are maintainers of technical agents (performing tasks in the field of maintenance and repairs of these means). Such people experience in the workplace (Braun, 2008, Sękowski, 1993):

- worsening eyesight, because the pupils react much slower to change the brightness of the lighting, slower adapt to the vision in the dark, while being more sensitive to all types of glare. The difficulty in focusing on the reading of small letters is also difficult because short-sightedness is progressing in this age. There are also problems with distinguishing between pastel colors, especially blue and green;

- hearing impairment (in particular, people exposed to noise). One of the problems associated with hearing impairment is loss of hearing acuity and the ability to hear certain frequency of audible waves, which leads to problems with verbal communication, especially in an environment where there is a high level of noise. The problem may also be damage to the inner ear, as well as the labyrinth, which is responsible for maintaining the balance of the body, which may result in a tendency to more frequent falls or dizziness;

- slowdown of reflex reactions due to aging of cells and receptors of the nervous system; 
- stronger and more sensitive reaction to poisons and other external factors;

- lower adaptability in conditions where the temperature is too low or too high;

- worsening sleep and reducing resistance to stress, and thus cannot switch from rest to work and vice versa;

- various other changes in the human body (including physiological changes).

In answer to the questions: who and how participates in the implementation of smart city solutions, a number of tasks should be indicated, the effect of which will be their application in order to improve the quality of life of societies, including the older people. These tasks may be represented by the diagram of the process of meeting needs, proposed by (Dietrych, 1985), which includes:

- need description;

- designing;

- constructing;

- production;

- exploitation.

In the deliberations under consideration, the construction and manufacturing stage will be omitted. The detailed steps of the process of meeting the needs indicate that the designer/constructor, producer in the smart city area and their user and maintainer are involved in the process. The last ones may be customers of transport organizations (passengers, users of the water supply system), users (drivers) and maintainers of transport means. Participants in transport systems - local authorities responsible for its functioning as well as the management of the transport company may also participate in the discussed participation.

The use of the above-mentioned scheme guarantees obtaining the answer to the question: how we intend to obtain the expected result of smart city implementation. On the stage of the needs description described in it, the needs are recognized and analyzed. The answer to the questions below can help in this task (Kaźmierczak, 2018):

- what is the source of the need?

- are we able to recognize and describe in which categories (qualitative, quantitative, mixed) ?

- what is the recognized need for?

- can you meet the recognized need ?

- how can you meet the recognized need?

- who can meet the recognized need?

- what are / can be the positive and negative effects of meeting the identified need ?

- what are / can be the positive and negative effects of not meeting the identified need?

Identification of the need is conditioned by technical factors (Kaźmierczak, 2018) the need may be the result of the analysis of objects in the process of their exploitation with the same or similar structure, events that occur in the use processes (intended and unintentional), as well as processes and systems of exploitation, the need may be a consequence of the development of technology as well as non-technical factors (e.g. the use of methods of creative problem solving). Different variants of factors generating needs in the field of technology are presented in Table 1. 
Table 1

Variants of factors generating needs in the field of technology

\begin{tabular}{|c|c|c|c|}
\hline Variants & $\begin{array}{c}\text { Previous experience in the use } \\
\text { of machinery and equipment }\end{array}$ & $\begin{array}{c}\text { Technology } \\
\text { development }\end{array}$ & $\begin{array}{c}\text { Non - technical } \\
\text { factors }\end{array}$ \\
\hline 1. & + & - & - \\
\hline 2. & + & + & - \\
\hline 3. & + & + & + \\
\hline 4. & - & + & - \\
\hline 5. & - & + & + \\
\hline 6. & - & - & + \\
\hline
\end{tabular}

Source: (Kaźmierczak, 2018).

Designing is about finding solutions that best meet the chosen criteria. This topic is addressed in (Grabarek, 2017, Dietrych, 1985). There are various design methods. Those that meet the needs of users of different ages, taking into account older people, can include:

- a universal design method (design for everyone);

- an empathic design method;

- methods of creative problem solving.

Universal design is to design products and environments so that they are accessible to all people, to the greatest extent possible, without the need for adaptation or specialized design (this definition was created by Ron Mace and was developed by the Universal Design Center at North Carolina State University).

In turn empathic design according to (Ćwiklicki at al., 2019) consists in observing people using current products or services in their own environment. It covers the following stages (Ćwiklicki at al., 2019):

- observation;

- collecting data;

- reflection and analysis;

- brainstorming;

- development of prototypes.

Among the methods supporting the design of technical means that will be used by the older people, bionics can be distinguished. Bionics is a science about the structure and principle of action of organisms and their adaptation in technology (especially in automatics) and the construction of technical devices on the model of the organism. Its essence and use in the design of technical means has been described in (Huang and Siao, 2016, Malaek and Farhangi, 2013, Samek, 2010). It will be considered in subsequent articles prepared by the authors.

Conducting activities specified in the scheme of the process of meeting needs, proposed by prof. Janusz Dietrych should be made on the basis of information from the exploitation of technical means in a smart city. This scheme assumes an informational feedback between the exploitation stage and the stages of: description of the need, design, construction and production. From the point of view of smart city considerations, the most interesting is the transmission of information about the exploitation of a technical measure in order to re-describe the need. The information conveyed in this way can be an assessment of the quality of life of older people. Such an assessment may be carried out using various methods, including methods in the area of technology assessment, methods of marketing and market research, methods used in social sciences (in psychology and sociology), etc. 
The assessment of smart city solutions, conducted to determine the quality of life of older people, can also be carried out using management methods. As an appropriate method of benchmarking, characterized in (Parmenter, 2016) can be pointed out particularly. The subject of benchmarking as a vehicle assessment tool was taken in (Debnath et al., 2014, Huovila et al., 2019). In (Huovila et al., 2019) for (Bosch et al.) indicators were classified. At the same time, the possibilities of their use were given. In (Debnath et al., 2014) the subjects of indicators used in the assessment of transport are presented, paying special attention to those that make transport intelligent. The subject of the quality of life in smart cities was taken in (Macke et al., 2018). In (Behrendt, 2016) the topic of the role of bicycles in the functioning of a smart city is presented. The method of determining the comfort of traveling with these technical means is presented in (Tabib et al., 2017).

An example of the application of benchmarking in the assessment of the transport system, which is the water supply network, is presented in (Loska, 2013, Loska, 2016, Loska, 2017). The subject of interest in the mentioned literature items are economic, technical and organizational indicators recorded in EN PN 15341 standard. For the purpose of analyzing the value of indicators, a mathematical model was developed, which includes the scenario method.

Previous literature studies allow to state that one of the basic mistakes made when formulating a strategy for transport in a city is to focus on technical solutions in the smart city area in isolation from social participation aimed at their implementation. There are no quantitative methods of social evaluation in the literature. That is why the task of proposing it was undertaken.

\section{THE METHOD OF IMPROVEMENT OF QUALITY OF LIFE OF OLDER PEOPLE AS USERS AND MAINTAINERS OF TECHNICAL MEANS IN SMART CITY}

Literature research on the concept of implementation of smart city solutions results in the need to develop measures to assess the quality of life of people of all ages, including older people, as users/maintainers of technical means. Therefore, the concept of an indicator of such an assessment was proposed. It takes the following form (Wieczorek, 2019):

$$
W_{i}=\sum_{i=0}^{n}\left(P_{i} \cdot K_{i}\right)
$$

where:

$W$ - value of measure of reliability, maintainability/reparability, quality etc.

$P$ - probability of occurrence of measure value

$K$ - assessment $(1-5$, where 1 - the lowest value of phenomenon, $5-$ the highest value of phenomenon)

The essence of the method consists in developing $W_{i}$ characteristics as a function of the age of a person. The assessment of the quality of life of older people with the use of the mentioned characteristics can be carried out on the basis of answers to questions asked in the questionnaire submitted to the users and maintainer of means of transport. The selected questions of questionnaire are presented below.

- Do you think that $X$ city - buses $X$ are durable enough ?

- Do you think that $X$ city - buses are characterized by low failure rates?

- What should the city - bus durability be? 
- Do you think that $X$ city - buses are outdated?

- Do you feel threatened as a passenger of the $X$ city - bus?

- Is there enough seats in the $X$ city - buses ?

- Is there enough seats at the bus stops?

- Is driving a $X$ city - bus comfortable ?

- Do you have a problem getting on and off the X city - bus?

- Is the information on bus departures at the bus stops clear?

- Is the travel costing system functional?

- Is the cost of travel optimal?

- Is the frequency of bus arrivals sufficient?

\section{CONCLUSIONS}

A smart city is the answer of engineers to the need to improve the quality of life of its residents at different ages. The creation of technical solutions in this area, which will contribute to this improvement, should however be preceded by social participation, because focusing only on the technical aspects of an intelligent city is not enough to ensure the quality of life of the older people.

The quality of life through the use of engineering methods and methods of technology assessment has a chance to become the object of interest of engineers. It is necessary to continue work on their application as tools for their work. The indicator proposed in the article may be the first step in this direction.

Thanks to the opinion of older people as users of technical means, it will be possible to use the subjective view of the technical means, exploitation events that occur in its operation, processes and systems of its exploitation. This look will allow for a full assessment of the technical mean in its operation, including the needs related to it, which the older people have.

\section{ACKNOWLEDGEMENT}

The research was conducted with the support of the statutory work titled "Creating intelligent production methods, working environments and life in the context of production engineering discipline", project number 13/030/BK-18/0039.

\section{REFEENCES}

Behrendt, F. (2016). Why cycling matters for Smart Cities. Internet of Bicycles for Intelligent Transport. Journal of Transport Geography, 56, pp. 157-164.

Bosch, P., Jongeneel, S., Rovers, V., Neumann, H.-M., Airaksinen, M., and Huovila, A. CITY keys indicators for smart city projects and smart cities. Available at: http://nws.eurocities.eu/MediaShell/media/CITYkeysD14Indicatorsforsmartcityprojects andsmartcities.pdf. [Accessed 28 January 2018].

Braun, L. (2008). Wzrasta średnia wieku pracowników. Available at: www.utrzymanieruchu.pl. Data odczytu: 1.02.2008. [Accessed 1 February 2008].

Brodny, J., Tutak, M. (2019). Analysing the Utilisation Efectiveness of Mining Machines Using Independent Data Acquisition Systems: A Case Study. Energies, 12, 13 (2505), pp. 115

Brodny, J., Tutak, M. (2018). Analysis of Methane Hazard Conditions in Mine Headings. Published on HRČAK: Tehnički vjesnik - Technical Gazette, 25(1), February 2018, pp. 271-276. 
Brodny, J., Tutak, M. (2018). Determination of the Zone with a Particularly High Risk of Endogenous Fires in the Goaves of a Longwall with Caving. Journal of Applied Fluid Mechanics, 11(3), pp. 545-553.

Ćwiklicki, M., Jabłoński, M., Włodarek, T. Samoorganizacja w zarządzaniu projektami metodą Scrum. Available at: Mfiles.pl. [Accessed 7 July 2019].

Debnath, A. K., Chin, H. C., Haque, Md. M., Yuen, B. (2014): A methodological framework for benchmarking smart transport cities. Cities, 37, pp. 47-56.

Dietrych, J. (1985). System i konstrukcja. Warszawa: WNT.

Grabarek, I. (2017). Projektowanie ergonomiczne środków transportu miejskiego. Warszawa: Oficyna Wydawnicza Politechniki Warszawskiej.

Harvard Business Essentials. (2006). Coaching i mentoring. Jak rozwijać największe talenty i osiągać lepsze wyniki. Warszawa: MT Biznes Sp. z o.o.

Huang, J.Y., Siao, S.T. (2016). Development of an integrated bionic design system. Journal of Engineering, Design and Technology, 14(2), pp. 310-327 .

Huovila, A., Bosch, P., Airaksinen, M. (2019). Comparative analysis of standardized indicators for Smart sustainable cities. What indicators and standard to use and when ? Cities, 89, pp. $141-153$.

Kaźmierczak, J. (2019). Jak można i trzeba postrzegać problemy tworzenia i funkcjonowania „inteligentnego miasta”? A presentation at the Conference „Inteligentne miasta”, RP Parlament.

Kaźmierczak, J. (2018). Uwagi na temat rozpoznawania i analizy potrzeb w procesach oceny technologii. Zeszyty Naukowe Politechniki Śląskiej serii „Organizacja i Zarządzania”, 115 , pp. 155-169.

Kaźmierczak, J., Janik, A., Midor, K., Wieczorek, A. (2017). Koncepcja badań nad relacjami wiążącymi jakość funkcjonowania sieciowych instalacji dystrybucyjnych $\mathrm{w}$ miastach z jakością życia mieszkańców na przykładzie systemu wodociągowego. Systemy Wspomagania w Inżynierii Produkcji, 6(7), pp. 117-128.

Loska, A. (2016). Metodyka modelowania eksploatacyjnego procesu decyzyjnego z wykorzystaniem metod scenariuszowych. Gliwice: Wydawnictwo Politechniki Śląskiej.

Loska, A. (2017). Scenario modeling exploitation decision-making process in technical network systems. Eksploatacja i Niezawodność, 19(2), pp. 268-278.

Loska, A. (2013). Eksploatacyjna ocena wybranych obiektów technicznych z zastosowaniem metod taksonomicznych. Eksploatacja i Niezawodność, 15(1), pp. 1-8.

Macke, J., Casagrande, R. M., Sarate, J. A. R. and Silva, K. A. (2018). Smart city and quality of life: Citizens' perception in a Brazilian case study. Journal of Cleaner Production, 182, pp. 717-726.

Malaek, S. M. B., Farhangi, H. (2013). From biology to the man-made systems. Kybernetes, 42(7), pp. 1086-1100.

Palka, D. (2017). The role and importance of training for improving the safety and awareness of the technical staff in the mining plant. In: CBU International Conference Proceedings: Innovations in Science and Education, 5, pp. 1195-1198.

Palka, D., Brodny, J. and Stecula, K. (2017). Modern means of production and the staff awareness of the technical in the plant of the mining industry. In: CBU International Conference Proceedings 2017: Innovations in Science and Education, 5, pp. 11901194.

Parmenter, D. (2016). Kluczowe wskaźniki efektywności (KPI). Tworzenie, wdrażanie i stosowanie. Creation, development and application). Gliwice: One - Press.

Raport dotyczący potrzeb starszych ludzi, zlecony przez Ministerstwo Ochrony Środowiska Transportu i Regionów Transportowych (DETR).

Samek, A. (2010). Bionika. Wiedza przyrodnicza dla inżynierów. Kraków: Wydawnictwo AGH.

Sękowski, A. (1993). Adaptacja psychiczna osób w podeszłym wieku do warunków życia. Lublin: Wydawnictwo Uniwersytetu Marii Curie-Skłodowskiej.

PWN Dictionary. Available at: https://sjp.pwn.pl. [Accessed 6 July 2019]

Tabib, M. V., Rasheed, A. and Uteng, T. P. (2017). Methodology for assessing cycling comfort during a smart city development. Energy Procedia, 122, pp. $361-366$.

Tutak, M. and Brodny, J. (2019). Predicting Methane Concentration in Longwall Regions Using Artificial Neural Networks. International Journal Environmental Research Public Health, 16, 1406; pp. 1-22. 
Wieczorek, A. (2013): Rola inżynierii produkcji w rozwiązywaniu problemów starzenia się społeczeństwa - studium literatury. In: Systemy wspomagania w inżynierii produkcji. Wspomaganie zarządzania systemami produkcyjnymi. Witold Biały, Michał Zasadzień, ed., Gliwice: Wydawnictwo P.A. NOVA, pp. 148-164.

Wieczorek, A. (2019). Koncepcja metody społecznej oceny technologii wspomagających funkcjonowanie osób starszych jako ich użytkowników i obsługujących. Unpublished manuscript.

Wnuk, A. and Grabarczyk, P. (2006). Problemy osób niepełnosprawnych i starszych w ruchu drogowym. Bezpieczeństwo ruchu drogowego, 4, pp. 12-14.

Abstract. The article attempts to identify opportunities to improve the quality of life of older people by implementing smart city solutions. Literature research presented in it contains answers to the following questions: what is planned to be achieved as a result of the smart city concept implementation, why this concept is implemented, who participates in this task and how to achieve the expected result of smart city implementation. In response to the first and second question, attention is paid to the needs of older people - smart city solutions exploitators, associated with a specific type of transport, which must be met to achieve quality of life at a certain level. The answer to the third question is an indication of the participants, such as designers, constructors, producers of solutions in the area of the smart city, as well as their exploiters. The last ones may be customers of transport organizations (passengers, users of the water supply system), users (drivers) and maintainers of transport means. Participants in transport systems - local authorities responsible for its functioning as well as the management of the transport company - may also participate in the discussed participation. Tasks that should be given to individual participants in the process of meeting needs have been defined. It was also pointed out that their role should not focus solely on technical aspects, but social participation is of particular importance, on which the quality of life of people in society depends.

Therefore, the selected method of technology assessment, which together with engineering methods should condition the course of the process of satisfying the needs aimed at obtaining the desired solutions in the smart city area, have been indicated. The result of the conducted research is the concept of an indicator that supports the process of technology assessment in the smart city area. Along with this concept, examples of questions which may form the basis of calculations with its use are listed.

Keywords: smart city, quality of life, older people, technology assessment 